\title{
Adolescencia (NI SANTO Ni MÁRTIR)
}

Ve a un rincón hasta que dejes de pensar en osos blancos.

En algún momento perdí la inocencia del niño engañé a los profesores aprendí a dormitar mientras recitaba fechas históricas (Soy un muchacho quiero contemplar las nubes e ir detrás de las mujeres y sus faldas sus estrechas faldas que tiemblan con el ritmo incansable de sus pasos y reviven muertos por la calle)

Mira las casas y sus fachadas de colores que se mezclan mira las nubes como animalitos sucios en un desfile luminoso mira cómo me tumba en la cama el sopor de la cerveza

Soy el eterno estudiante

que garabatea sobre su cuaderno y vive de cara al sol

Afuera, sentado en la banqueta, espero una señal pero hoy no voy a esperar Hoy no porque hoy es mi día de suerte 